\title{
Local Government and Community Efforts in the Development of Kalaodi Agrotourism, Tidore Archipelago City, Indonesia
}

\author{
Abdurrahman Kader* \\ Study Program of State Administration, Faculty of Social and Political Sciences, Universitas Muhammadiyah Maluku \\ Utara, Ternate, Indonesia
}

\begin{abstract}
This research aimed to examine the development of Kalaodi Agrotourism, the development of tourism facilities in the Kalaodi Agrotourism area, and the development of human resources in the tourism sector carried out by local governments and communities. This research used a qualitative descriptive approach, and it used an interactive model as the data analysis technique. The results showed that Kalaodi had many kinds of tourism wealth, specifically, in the form of nature, agro, and cultural tourism. The Kalaodi community had the will and enthusiasm to develop tourism objects in their area. There were various public transportation facilities such as roads, good sanitation, electricity facilities, and communication facilities even though Kalaodi was a village located far from the central government and urban areas. In addition, the Kalaodi community had developed human resource development programs, such as the creation of literacy houses, the formation of art galleries, English language training, and home industry product development training. In developing agrotourism, the collaboration between the local government and the community is needed, both in the development of tourist objects and tourism support facilities.
\end{abstract}

Keywords: Development, Kalaodi Agrotourism, Tidore

\section{INTRODUCTION}

Kalaodi is a small village, which by the administration is an urban village located in Tidore Subdistrict, Tidore Archipelago City. Topographically, Kalaodi is an area with hilly and valley topography. This area is located approximately 700 meters above sea level, and approximately $4 \mathrm{~km}$ from the center of the city and the government, and approximately $6.7 \mathrm{~km}$ from the capital of the subdistrict [1].

Kalaodi community village is surrounded by community plantations of clove, nutmeg, durian, malinjo (Gnetum gnemon), bamboo, and others. These annual plants thrive and become the leading source of life for the Kalaodi community. The nature of Kalaodi is inseparable from its geographical existence, which is geographically located on Tidore Island, in North Maluku Province. In general, the North Maluku region has a tropical climate type. The dry season, which occurs from December to March, and the rainy season, which occurs from May to October, are caused by the southeast monsoon, and the transition season occurs in April and December. In general, North Maluku rainfall is 2,570-3,050 $\mathrm{mm}$ per year or an average of $2000 \mathrm{~mm}$, therefore this area is classified as type $A$

* Correspondence address:

Abdurrahman Kader

Email : rahmankader78@gmail.com

Address : Universitas Muhammadiyah Maluku Utara,

St. Mononutu No. 10 Tanah Raja, North Maluku 97716 climate or wet climate. In the classification of agroclimatology, areas like this are included in the E1 zone, wherein one hand, wet months occur within three months per year, and on the other hand, dry months last less than two months [2].

Specifically in the Tidore Archipelago City region, the maximum average temperature is $31.3^{\circ} \mathrm{C}$, the minimum average temperature is $21.2^{\circ} \mathrm{C}$, the average humidity is $83.5 \%$, the average solar radiation is $67.5 \%$ per year, and the average air pressure is 1001.9 bar [2]. With this kind of weather conditions, the Tidore Archipelago City area is very fertile, makes it easier for the community to grow crops and produce a variety of agricultural and plantation products as a source of livelihood. Kalaodi is rich in agricultural and plantation resources because this region is located on Tidore Island, which has a good climate for agriculture. With this favorable climate, the land of Kalaodi has grown a variety of agricultural and plantation products, which enriched the agricultural resources.

Therefore, the Government of Tidore Archipelago City by Regional Regulation No. 25 of 2013 concerning Tidore Archipelago Spatial Plan for 2013-2033, and Regional Regulation No. 9 of 2015 concerning the Regional Tourism Development Master Plan (RIPPARDA) of Tidore Archipelago City for 2015-2030, making Kalaodi as one of the regional agrotourism objects. To achieve these policy expectations, real programs and activities are needed by the government and the community $[3,4]$. 
(Kader)

However, in its work program and activities, the Department of Culture and Tourism of the Tidore Archipelago City has no planned activities for the development of Kalaodi Agrotourism. It can be seen in the work plans and activities of the Department of Culture and Tourism of the Tidore Archipelago City. Ideally, local governments should have programs and activities that are specifically related to the development of Kalaodi Agrotourism as a form of implementation of local policies in the tourism sector. Among the approaches that can be taken by local government in developing regional tourism destinations is to strengthen the regional innovation system in the tourism sector [5].

Based on this phenomenon, in general, this research aimed to examine the development of Kalaodi Agrotourism carried out by local governments and communities. Specifically, this research aimed to examine the development of Kalaodi Agrotourism, the development of tourism facilities in the Kalaodi Agrotourism area, and the development of human resources in the tourism sector carried out by local governments and communities.

\section{RESEARCH METHODS \\ Study Area}

This research was conducted in Kalaodi Village, Tidore Archipelago City, North Maluku Province. Economically, agriculture and plantations are the main sources of livelihood for the Kalaodi community The Kalaodi community has also developed a home industry that produces various snacks and souvenirs with local characteristics and flavors. Socially and culturally, the Kalaodi community is peaceful and one with nature, with various local wisdom. Based on regional policies,
Kalaodi is one of the agrotourism objects in Tidore Archipelago City and a regional leading tourist attraction $[3,4]$. The main problem of this research is development of Kalaodi agrotourism carried out by local governments and communities.

\section{Data Collection}

This study used a qualitative descriptive approach, and data sources were obtained using human instruments, events, and documents. The qualitative method is an instrument used to investigate phenomena or events that occur in everyday life that are considered attractive, whether in individuals, groups, communities, and organizations. With qualitative methods, the researcher gets a holistic and systemic, and integrated overview of the context under study, including social arrangements, ways of working, and the underlying rules, both explicit and implicit [6]. Data collection was carried out through interviews with key informants, observations in the Kalaodi agricultural area, and documents related to Kalaodi agriculture.

\section{Data Analysis}

The data analysis technique used was interactive models, with the following stages: data condensation, namely the process of selecting, simplifying, or changing data arising from written notes in the field, interview transcripts, documents, and other empirical materials. Furthermore, display data is the process of describing data and information in research reports that provide the possibility of concluding. The next stage is the drawing/verifying of the interpretation activity, namely finding the meaning of the data that has been presented [6]. All data used in this stage comes from interview data, observations, and documents of Kalaodi agrotourism development.

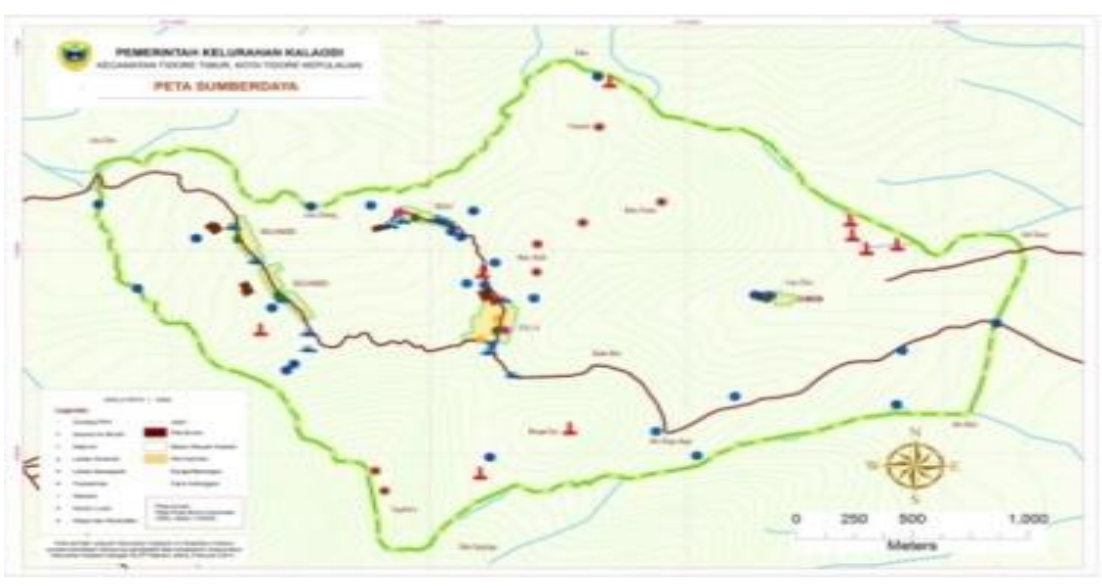

Figure 1. Map of Kalaodi Urban Village Area (Source: Kalaodi Urban Village Office, 2018) 


\section{RESULTS AND DISCUSSION}

Development of Kalaodi Agrotourism Object

Conceptually, efforts should be made in developing tourism objects. Tourism development is essentially an effort to develop tourism objects and attractions in tourist destinations. The real form and results of these efforts are natural beauty, diversity of flora and fauna, diversity of traditions and culture, as well as historical heritage [7].

Related with components in the development of tourist destinations, there are elements in the development of tourist destinations, including the attractions [8]. Attractions of tourism objects are one element or component in the concept of tourism. The development of tourist destinations is the physical development of tourist attractions [9]. In the framework of developing tourism, what must be built are tourism objects and attractions, which include attractions that are usually based primarily on natural, cultural, or artificial wealth, such as events or which are often referred to as special interests [10].

In general, the development of attractions in Tidore Archipelago City is not in accordance with regional policy expectations. For the development of Kalaodi Agrotourism, the local government does not have a specific program and activity planning. The problem faced by the region in the development of tourism is the budget problem. With a limited budget, the local government is forced to carry out priority programs and activities to develop tourism objects. Based on empirical reality related to the development of attractions, the government of the Tidore Archipelago City prioritizes the development of attractions in Tugulufa Beach and Ake Sahu Beach, as well as Tidore anniversary cultural events.

Although it has not received the local government's attention, the village government and the Kalaodi community have the enthusiasm to develop and improve the area as an agrotourism object under the spirit of regional policies. From the side of the urban government, for example, the government commits to developing tourism objects in its area. For example, the Kalaodi Urban government has always programmed and proposed every Musrembang (planning and development meetings) activity to develop supporting facilities for the Luku Celeng Waterfall tourist attraction. The discussion included the construction of access roads to waterfalls and the construction of a gazebo around the waterfall.

In addition, the urban government conducts a forest protection program around the waterfall by reforestation. Another effort to protect the forest around the waterfall carried out by the urban government is working together with Traditional Leaders and the community to enforce customary rules on the prohibition of tree logging around the waterfall. On the other hand, the Traditional Leaders and the Kalaodi community also carry out the traditional rituals of Paca Goya and obey the traditional rules of Bobeto. The traditional rituals of Paca Goya and the traditional rules of Bobeto are the wisdom of the community regarding forest and nature protection.

The traditional ritual procession of Paca Goya and Bobeto was carried out by the customary leaders of the Kalaodi community, who are commonly called Sowohi. On the day of the ritual, the Kalaodi community led by Sowohi walked to the place for the ritual called Goya (Fig. 2). In that place, traditional food, is served and prayer rituals are led by Sowohi. After the prayer is read by Sowohi, then continue with the ritual of eating traditional food which is carried out in a wise and sacred manner. In the procession of the Paca Goya and Bobeto traditional rituals, the entire Kalaodi community is involved (Fig. 3).

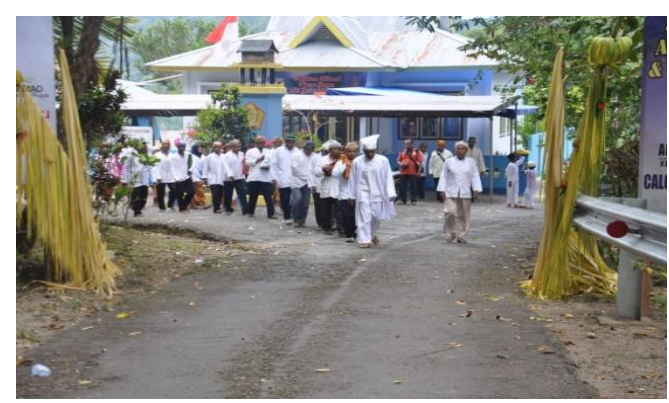

Figure 2. Procession Walks Towards the Paca Goya Ritual Place by the Kalaodi Community (Source: Kalaodi Urban Village Office, 2018)

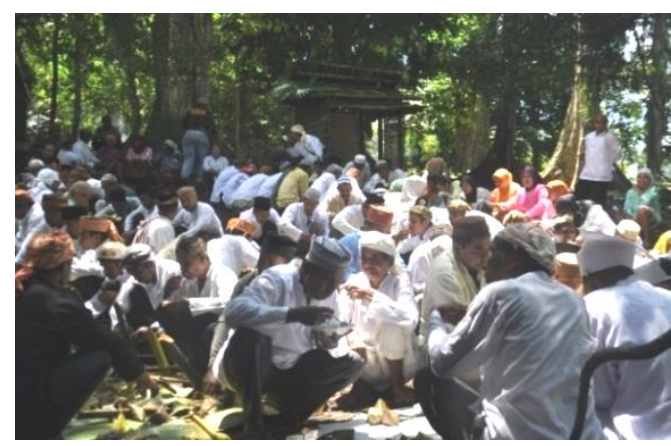

Figure 3. Traditional Food Eating Procession in the Paca Goya Ritual Event by the Kalaodi Community (Source: Kalaodi Urban Village Office, 2018) 
In addition to the commitment of the urban government, the community also has the same spirit. The effort and enthusiasm of the Kalaodi community to develop and improve agrotourism in the regions are quite high. The people keep and protect nature and the surrounding forests by applying the Bobeto customary rules and with great enthusiasm to attend and follow the Paca Goya traditional ritual. Collaboration between the government and the community in developing a culture to become a tourist object has beneficial values for the community and also as a medium for the development of tourism facilities [11].

Not only that, the people have been developing a variety of home industries that produce a variety of unique snacks with raw materials originated from agriculture and plantations. The community also empowers home industries that produce a variety of souvenirs made from Kalaodi forests. Another effort undertaken by the Kalaodi community to develop its agrotourism is by conducting the Festival Buku Se Dou Kalaodi. The festival has several agenda of events that have educational value and it also acts as a tourist attraction. Among the agenda of the activities contained in the event are cultural seminars, performances of arts and typical culture of Kalaodi, exhibitions of traditional technology of agricultural production processing equipment, typical food and snacks of Kalaodi, and community handicrafts.

Another effort made by the Kalaodi community to develop tourism in the village is through the younger generation's activities by forming art galleries. The art studio was formed by Karangtaruna (Youth Organization) of Kalaodi Urban Village, with the name Buku Se Dou. This reality shows that the young generation of Kalaodi also has the spirit to develop their village. The activity indirectly contributes to developing tourism in the village. Conceptually, the business carried out by the Kalaodi community is an effort to develop tourism objects. The objects and the attractions include the usual attraction based primarily on natural, cultural, or artificial wealth, such as events or what is often called a special interest $[8,10]$. The dynamics of the development of tourist villages were caused by several factors: availability of human resources, the potential of tourist villages, and tourism awareness of tourist village communities [12]. Among the strategies to create tourist attractions are educating local people in tourism management, developing tourism products, and promoting tourist objects [13].

The activity carried out by the urban government and the Kalaodi community indirectly supports the local government's policy to develop the village as an agrotourism attraction. Agrotourism is the community-based tourism activities that utilize the agricultural business [14]. Agrotourism or agricultural tourism can be interpreted as a series of tourist travel activities that utilize the agricultural location or sector from the beginning of production to obtain agricultural products in various systems and scales to expand knowledge, understanding, experience, and recreation in agriculture [15].

The local government must appreciate the Kalaodi community's awareness of building their village to develop tourism because active support and participation from the community of all stakeholders are needed in the concept of tourism development. To develop industrial and tourism infrastructure, all parties need to work together with like-minded stakeholders in government and industry [16]. Cooperation between stakeholders, such as the government, the industrial sector, and the community that creates tourism products and services are needed. Thus, it can attract tourists to visit tourist destinations.

One of the keys to the success of tourism development is the importance of community participation and involvement in all stages of development implementation. The community must be involved in the planning, implementation, monitoring, and evaluation stages. Communities involved in each stage of development are expected to convey ideas and thoughts as well as their interests. The existence of the community must be an equal, guaranteed, and effective partner. The partnership should guarantee the involvement of the community and other stakeholders in a framework for managing tourism that is under the vision and character of the local community [17].

\section{Development of Tourism Facilities}

In the concept of tourism, tourism facilities are basic needs that must be available in tourist destination areas. Apart from being a tourist necessity facility, tourism facilities are a supporting factor in developing and improving tourism. Thus, tourism facilities are supporting facilities of a tourist destination that are needed to serve tourists' needs in enjoying their tour. 
Conceptually, the components of tourism facilities that must be available in tourist destinations in tourism development are Accessibility, which includes transportation system support that includes: transportation routes and modes of transportation used to reach tourist attractions; Amenities, which include supporting tourism facilities, which include: accommodation, restaurants and food, restaurant and retail; Supporting infrastructure, namely all types of public facilities in the form of physical infrastructure such as ports, airports, train stations, terminals, and electricity and water supply facilities, and toilets; Supporting facilities (ancillary services), namely the availability of supporting facilities used by tourists, such as banks, telecommunications, hospitals, souvenir shops, and other leisure facilities [10].

Using the above concept, the most important facility that must be available and provided within the Kalaodi Agrotourism development framework is accessibility or road access to Kalaodi; amenities or availability of accommodation and restaurants; electricity, telecommunications, clean water, and toilet facilities. The importance of the availability of tourism facilities is so that tourists can access and enjoy tourist attractions safely and comfortably.

In developing Kalaodi agrotourism by using the concepts mentioned above, the Kalaodi village meets the standards of the concepts. In the accessibility component, for example, access to the Kalaodi village is very easily supported by paved road facilities with excellent road conditions. Access to the Kalaodi village has been supported by land transportation infrastructure, a paved road that has connected every hamlet in Kalaodi village [18].

Kalaodi is geographically located $4 \mathrm{~km}$ from the central government, and the distance from the capital of the subdistrict is approximately $6.7 \mathrm{~km}$, at an altitude of approximately $700 \mathrm{~m}$. However, in terms of accessibility, it is not isolated [1]. There are various transportation modes used by tourists to visit the Kalaodi village, such as ojek or hired motorcycle, city transportation, and rental cars. Access to the Kalaodi village can be done through two channels the eastern route through the Cobodoe Jati Urban Village, East Tidore Subdistrict, and through the western route with its entrance through the Ome and Foboharu Urban Village, North Tidore Subdistrict.

In addition to accessibility, amenity, or availability of accommodation (lodging) and restaurant is one of the facilities that must be present at a tourist destination. Kalaodi Agrotourism Village has no lodgings and restaurants. However, Kalaodi community initiatively provides and makes their homes homestays because foreign tourists are visiting and staying overnight at Kalaodi.

Facilities and other important facilities that must be built and provided in the construction and development of tourism are electricity, telecommunications, clean water, and toilet facilities. The availability of supporting public facilities in the tourism system in the form of electricity, telecommunications, clean water, and toilets is a supporting need for tourists. Related to this, in the regional context, based on data from BAPPEDA of Tidore Archipelago City [19], various public infrastructure facilities are available that are the needs of the people of Tidore Archipelago City, and also as a support for tourism development in Tidore Archipelago City. Various public facilities that have been provided by the regions within the framework of regional development include the provision of clean water, telecommunications, hospitals, banks, electricity, and others.

In the Kalaodi case, clean water facilities have been provided in 13 units of reservoirs built by local governments [1]. The reservoirs of clean water have been utilized by the community as a source of household health needs. In addition to the public clean water facilities, there are clean water storage facilities that are built privately by the community to meet their daily needs in each house.

Other important public facilities that must be available in a tourism destination are electricity and telecommunications. Kalaodi, as explained earlier, is geographically over 700 meters high, and the distance from the government center is approximately $4 \mathrm{~km}$, but that does not make Kalaodi village isolated from the communication and electricity facilities.

The concept of tourism development implies that the tourism system requires supporting public facilities. Supporting public facilities that must be available at tourist destinations includes clean water, telecommunications facilities, electricity, banks, and other public facilities In the framework of tourism development, the components that must be built include the following infrastructures. First is supporting infrastructure, namely all types 
of public facilities in the form of physical infrastructures such as ports, airports, train stations, terminals, and electricity and clean water facilities, and toilets. Second is ancillary services, namely the availability of supporting facilities used by tourists, such as banks, telecommunications, hospitals, souvenir shops, and other leisure facilities [10].

In the framework of tourism development, carrying capacity is the availability of public facilities in the area of tourism objects visited in the tourist destination. Therefore, tourism infrastructure needs to be built in accordance with the location and condition of the tourist attraction concerned. Public facilities that are prepared for the needs of tourists in tourist destinations consist of electricity, water, telecommunications, banks, pharmacies, hospitals, gas stations, shopping centers, and so on [20].

The most important thing is the availability of supporting public facilities in a tourist destination area to establish a good image and opinion of the tourist destination. The formation of a good image and opinion of tourists towards a tourist destination is an important strategy in tourism development. It is also an effective promotional media. To create and maintain a positive image of tourists towards tourist destinations, what must be maintained in a tourist destination is environmental cleanliness, the quality of tourism infrastructure. With good environmental quality and availability of infrastructure and good tourism facilities, it gives a sense of security and comfort to tourists. On the other hand, with a sense of security and comfort, it will form a positive opinion from tourists about the tourist destination. Thus, assessment and positive opinions from tourists is an effective promotional media [21]. To attract more visitors and increase their satisfaction, increase their perception of the destination image by making improvements to facilities [22].

\section{Development of Human Resources}

Human resources are one of the resources in regional economic development. Human resources include skilled labor with an entrepreneurial spirit and institutional resources [23]. Human resource development in the context of tourism development is a primary need. The development of human resources in tourism can be done with a formal education and training approach. Formal education and training are carried out on government officials, tourism industry entrepreneurs, employees in the tourism industry, and the people who are in the tourism area [24]. Efforts to develop human resources are to support the development of tourism in the area.

Referring to the concept of human resource development in tourism mentioned above, the region that has conceptualized itself as a tourist destination must prepare its human resources. Kalaodi has become one of the leading tourism objects in the region as regulated in Regional Regulation No. 9 Year 2015 concerning the Regional Tourism Development Master Plan (RIPPARDA) of the Tidore Archipelago City for 2015-2030, the development of human resources, especially in the field of tourism becomes a necessity. For this reason, the development of human resources in the Kalaodi community is included in the framework for the development and improvement of Agrotourism in Kalaodi that needs to be carried out.

The development of human resources in tourism must be done synergistically between the government and tourism business actors and the community in the tourist destination. The synergy between the activities of tourism stakeholders in the development of human resources in tourism is important because each stakeholder has its role in the development and improvement of tourism. One element that supports the interest of tourists to come to a tourist destination is the community around the tourist attraction who will welcome the presence of tourists and will provide services needed by tourists [20]. Therefore, the community around attractions needs to know the various types and quality of services needed by tourists.

Thus, human resources have an important and strategic role in tourism development. Industrially, human resources in tourism development are a driving force for the continuity of the tourism industry. On the other hand, the key position in the existence of human resources in tourism development acts as the main actor who creates products and services, which is one of the main factors determining competitiveness in the tourism industry [9].

The government as regulator and facilitator must prepare policies and regulations as a legal umbrella for development in the field of tourism. In addition, the government must also facilitate business people and the public to invest and expand regional tourism wealth. On the investment side, investors invest in developing the 
tourism industry and are interested in creating a variety of tourism products and providing tourism services in their travels. Institutionally or personally, the people who live in the tourist destination synergize with the government and other stakeholders to create human resources. If the human resources of the community in the tourist destination are well available, it will help the government and other stakeholders develop and improve regional tourism.

Related to the development of human resources in the field of tourism, the Kalaodi community has realized the importance of these problems. Kalaodi community awareness in developing human resources as a concrete action to prepare the village as a regional agrotourism attraction has been present. The Kalaodi community has taken concrete actions to prepare themselves as a tourism destination, such as forming an art studio and conducting training activities on developing home industry products developed by the community such as chips, bamboo matting, and other products. The home industry development activities carried out by the Kalaodi community can be seen in Figure 4.

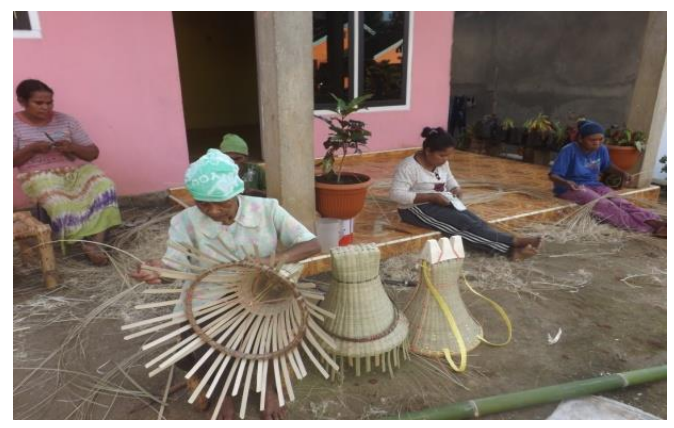

Figure 4. Kalaodi Community Activities to Make Bamboo Matting (Source: Kalaodi Urban Village Office, 2018)

Referring to this reality, it can be explained that the development of human resources, especially in this research, shows that the Kalaodi community has carried out human resource development activities as a rare endeavor for the development and improvement of tourism in the village. The Kalaodi initiative to develop human resources through training activities in mastering English, establishing literacy houses, and forming art galleries is indirectly a form of attention for tourism development in the village.

The attention of the Kalaodi community is a form of participation and support, as well as a form of a sense of responsibility towards local government policy in tourism development. Development at the ideal level should be the joint responsibility of the government and the people so that there is no claim that the government has the sole responsibility for development. Development is to empower the community individually and in groups to develop their potential so that they can utilize the resources they have for a better life [25].

The Tidore Archipelago City government also carries out efforts to develop human resources in the field of tourism through the Department of Culture and Tourism through training activities. Among the training in human resource development conducted by the Department of Culture and Tourism is homestay managers' training [26]. In the context of tourism development, the development and improvement of human resources have an important and strategic role. Industrially, the existence of human resources in the development of tourism functions as a driving force for the continuity of the tourism industry [9]. On the other hand, the key position of the existence of human resources in tourism development acts as the main actor who creates products and services, which is one of the main factors determining competitiveness in the tourism industry.

Thus, the development of human resources in the context of tourism development is a primary need. The development of human resources in tourism can be done with a formal education and training approach. Formal education and training are carried out on government officials, tourism industry entrepreneurs, employees in the tourism industry, and the people who are in the tourism area [24]. Efforts to develop human resources are to support the development of tourism in the area.

\section{CONCLUSION}

Kalaodi has a lot of tourism potential. This wealth underlies the local government in the regional policy to make Kalaodi one of the leading tourism objects in the region, especially agrotourism. However, there are no programs and activities created by the local government to develop and improve Kalaodi Agrotourism. Nevertheless, the community and the Kalaodi urban government are still trying to develop the natural and cultural wealth that has become an area of agrotourism.

Kalaodi, as a village, is located far from the central government, but in general, the availability of various public facilities has been built and provided by local governments. The provision of 
various public facilities is conducted to develop all sectors and areas of development in the area, including the tourism sector.

To develop tourism objects in the area, various components of the Kalaodi community carry out human resource development activities. Among the human resource development activities undertaken by the Kalaodi community are the creation of literacy houses, the formation of art studios, English language training, and home industry product development training.

\section{REFERENCES}

[1] Kalaodi Urban Village Office. 2018. Profile of Kalaodi Urban Village. Kelurahan Kalaodi. Tidore.

[2] Statistic Center of Tidore Archipelago City. 2018. Tidore Archipelago City in numbers. Statistic Center Tidore Archipelago City. Tidore.

[3] Tidore Archipelago City Government. Regional Regulation No. 25 of 2013 on Tidore Archipelago Spatial Plan (RTRW) for 2013-2033. Tidore Archipelago City Government. Tidore.

[4] Tidore Archipelago City Government. Regional Regulation No. 9 of 2015 concerning the Regional Tourism Development Master Plan (RIPPARDA) of the Tidore Archipelago City for 2015-2030. Tidore Archipelago City Government. Tidore.

[5] Meylani, N. D., K. Dea, and Y. Abdillah. 2020. Governing tourism destination with innovation system in Malang Regency. Journal of Indonesian Tourism and Development Studies 8(1), 39-44.

[6] Miles, M. B., A. M. Huberman, and J. Saldana. 2014. Qualitative data analysis: a methods sourcebook. $3^{\text {rd }}$ Ed. SAGE Publications, Inc. California.

[7] Yoeti, O. 2007. Pemasaran pariwisata. Angkasa. Bandung

[8] USAID. 2012. Tourism destination management: achieving sustainable and competitive results. USAID. Washington D.C.

[9] Ministry of Cooperatives and SMEs of The Republic of Indonesia. 2016. Green tourism village development guide book. Ministry of Cooperatives and SMEs Ministry of National Development Planning (BAPPENAS) - Ministry of Tourism - Ministry of Village,
Development of Disadvantaged Regions, and Transmigration - Ministry of Environment and Forestry - Panorama Foundation. Jakarta.

[10] Sunaryo, B. 2013. Kebijakan pembangunan destinasi pariwisata: konsep dan aplikasinya di Indonesia. GAVA Media. Yogyakarta.

[11] Rachman, A. F., and Y.C. Tekol. 2020. Cultural transformations into tourist attraction. Journal of Indonesian Tourism and Development Studies 8(1), 14-24.

[12] Choirunnisa, U., and R. Rachmawati. 2020. ICT usages in Yogyakarta's tourist villages development. Journal of Indonesian Tourism and Development Studies 8(2), 112-118.

[13] Rahmat, A. Hakim, H. Riniwati, and H. Yasin. 2020. The analysis potentials and sustainablity development of agroecotourism in Palopo, South Sulawesi. Journal of Indonesian Tourism and Development Studies 8(1), 50-57.

[14] Pangestuti, E., L. Hanum, and L. E. Wahyudi. 2018. Development of agrotourism in Kampung Kopi Amadanom, Malang. Journal of Indonesian Tourism and Development Studies 6(3), 194-199

[15] Budiarti, T., Suwarto, I. Muflikhati. 2013. Pengembangan agrowisata berbasis masyarakat pada usahatani terpadu guna meningkatkan kesejahteraan petani dan keberlanjutan sistem pertanian. Jurnal IImu Pertanian Indonesia (JIPI) 18(3), 200-207.

[16] Centre for Liveable Cities (CLC). 2015. Planning for tourism: creating a vibrant Singapore. CLC. Singapore.

[17] UNESCO. 2009. Pariwisata pusaka: masa depan bagi kita, alam dan warisan budaya bersama. UNESCO Office. Jakarta.

[18] Teng, I. 2017. Bobeto sebuah nilai kearifan lokal pembentuk ruang ritual antara manusia dengan alam di Kalaodi - Tidore. Local Wisdom 9(1), 12-22.

[19] Office of Regional Development Planning (BAPPEDA) of Tidore Archipelago City. 2014. Book of Leading Potential of Tidore Archipelago City. BAPPEDA. Tidore.

[20] Suwantoro, G. 2004. Dasar-dasar pariwisata. Andi. Yogyakarta.

[21] J. Li, W. G. Kim and I. A. Wong. 2017. Does destination perception differ based on traveler type? A case of the world gambling capital: Macau. Jurnal Tourism Planning and Development 14(1), 15-30.

[22] Faulina, E. Siregar, V. Novita, and S. Arimbi. 2020. Push and pull motivations on halal 
tourism. Journal of Indonesian Tourism and Development Studies 8(2), 71-78.

[23] Bryant, C. and L. G. White. 1982. Managing development in the third word. Westview Press. Boulder, Colo.

[24] Ministry of Tourism, Republic of Indonesia. 2016. Ministry of Tourism Performance Accountability Report Year 2015. Ministry of Tourism, Republic of Indonesia. Jakarta.

[25] Rachmawati, R. 2010. Pokok-pokok pikiran menuju kesuksesan pengembangan sumberdaya ekonomi lokal kabupaten Purworejo. National Symposium 2010: Towards Dynamic and Creative Purworejo, DPPM-UII. Yogyakarta, $11^{\text {th }}$ July 2010.

[26] Department of Culture and Tourism of Tidore Archipelago City. 2018. Documents on Programs and Activities of the Tidore Archipelago City Department of Culture and Tourism for the 2019 Fiscal Year. Department of Culture and Tourism of Tidore Archipelago City. Tidore. 